\title{
500 Yataklı Eğitim ve Araştırma Hastanesinde Kesici Delici Alet Yaralanmaları Tutum ve Bilgi Düzeyi Ölçüm Anketi Sonuçları
}

\author{
The Outcomes of the Attitude and Information Level Questionnaire-Survey \\ on Sharps Injuries in a 500-bed Training and Research Hospital
}

\author{
Emine Güngör Özdemir, Gönül Şengöz* \\ Bağcılar Eğitim ve Araştırma Hastanesi, Enfeksiyon Kontrol Hemşiresi, İstanbul, Türkiye \\ *Haseki Eğitim Araştırma Hastanesi, Enfeksiyon Hastalıkları ve Klinik Mikrobiyoloji Kliniği, Istanbul, Türkiye
}

Özet

Amaç: Sağlık çalışanları kesici-delici alet yaralanmaları riski ile karşı karşıyadır. Bu anket çalışması ile mevcut durumun tespiti ve alınması gereken önlemler gözden geçirilmiştir.

Yöntem: Hastanemizde çalışan 270 kişiye 18 sorudan oluşan anket uygulanmıştır. Anketin ilk altı sorusunda demografik bilgilere yer verilmiştir. İkinci bölümde kesici-delici alet yaralanmaları eğitimi alıp almadıkları ve maruz kaldıkları yaralanmaların hangi işlem sırasında olduğu, koruyucu ekipmanın varlığı, sonrasında neler yaptıkları sorgulanmıştır. Son bölümde de alınması gereken önlemler konusunda görüşlerine başvurulmuştur.

Bulgular: Çalışanların yarıdan çoğu genç yaş grubunda ve beş yıllık çalışma periyodunda yer aldı. Katılımcıların 76’sı bu konuda eğitim almıştı. Kan yolu ile bulaşan hastalıkların hepsini bilen katılımcı oranı \%65 idi. Hekimlerin 3/4'ü yaralandıklarını ifade ettiler. En sık yaralanma nedeni; kan alma olarak saptandı. Yaralanma sonrası yapılan en sık uygulama su ve sabun ile yıkama idi. Yaralanmayı izleyerek en sık birim sorumlusuna haber verilmişti. "Bir şey yapmadım" diyenlerin oranı \%25 idi ve nedeni sorgulandığında en sık "Önemsiz olarak gördüm" şıkkı işaretlenmişti. Koruyucu ekipman kullanım oranları düşük olarak saptandı. Yönetimden beklentiler arasında en sıkıkla verilen cevap ise çalışanların eğitimi idi.

Sonuç: Bu anket çalışması çalışanların perkütan yaralanmalar konusunda eğitim aldıklarını ama bir maruziyet durumunda hala bazı tedirginliklerin olduğunu ortaya koymuştur. Sonuç olarak; çalışanlar ve hastane idaresi açısından yeterli ve gerekli farkındalığın gelişmesi için yapılması gerekenlerin planlamasında anket sonuçları konuya ışık tutacaktır. (Haseki Tıp Bülteni 2013; 51: 11-4)

Anahtar Kelimeler: Kesici delici alet yaralanması, koruyucu ekipman, önlemler

\begin{abstract}
Aim: Healthcare professionals face a risk of sharps injuries. This questionnaire-survey was conducted to determine the current situation and the necessary precautions.

Methods: The survey including 18 questions was applied to 270 subjects working in our hospital. The first six questions were related to demographic characteristics. In the second part, the participants were questioned whether they have received training on sharps injuries, and the type of procedure at the time of injury, presence of protective equipment and their behavior following a sharps injury. The respondents were asked for their opinions of protective measures to be taken.

Results: More than half of the participants were young adults and the length of service varied from 1 to 5 years. $76 \%$ of participants received training on sharps injuries while $65 \%$ had knowledge of all the blood-borne diseases. Three-fourths of the physicians sustained a sharps injury. The most common reason for an injury was blood-letting. The most common post-injury application was washing the site with water and soap. The most frequent approach of ones who did nothing was to report the injury to supervisor. $25 \%$ of subjects answered "I did nothing" and selected the option "Considered unimportant". Low rate of protective equipment use was documented. The staff expected training from the administration most commonly.

Conclusion: This questionnaire-survey has suggested that most of the staff have received training on percutaneous injuries, however, they still had some concerns regarding actions to be taken in the event of an exposure. Consequently, outcomes of this survey will shed light on improving sufficient awareness of necessary arrangements for the prevention of sharps injuries. (The Medical Bulletin of Haseki 2013; 51: 11-4)
\end{abstract}

Key Words: Stab wounds, protection, measures 


\section{Giriş}

Sağılı çalışanları mesleki olarak birçok risk ve tehlike ile karşılaşabilmektedir. Bu riskler içerisinde en önemlileri, enfeksiyonlar ve kesici-delici alet yaralanmalarıdır (1). Sağlık çalışanları; iğne batması, perkütan yaralanmalar ya da sıçrama nedeniyle kanla geçen patojenlerin bulaşması açısından risk altındadır (2) ve mesleki nedenlerle enfekte kan ve vücut sıvılarına maruz kalmayı takiben önemli mortalite ve morbiditeye neden olabilen hepatit B (HBV), hepatit C (HCV) ve insan yetmezlik virüsü [human immunodeficiency virus (HIV)] gibi etkenlere bağlı enfeksiyon hastalıklarına yakalanabilir (3). Sağlık çalışanları toplumdan kazandıkları bu enfeksiyonları hastalara ve diğer sağlık çalışanlarına da bulaştırabilir (1).

Kesici delici alet yaralanmaları (KDAY) ilk olarak, şırınganın 1845 yılında ilk kez kullanılmasından bu yana tehlike oluşturmaya başlamış ve günümüzde de devam etmektedir. Dünya çapında her yıl hastalara 12 milyar enjeksiyon yapıldığı tahmin edilmekte ve $A B D^{\prime}$ de her yıl 800 bin iğne batması kaynaklı yaralanma meydana geldiği bildirilmektedir (2).

Günümüzde tek kullanımlık tıbbi malzemelerin kullanılması (enjektör, bistüri, lanset vb.), vakumlu tüple kan alma, delici ve kesici aletlerin delinmez enfekte atık kutusuna atılması gibi yaklaşımlarla perkütan yaralanmaların oranı önemli ölçüde azaltılabilmektedir. Ancak KDAY ülkemizde hala \%50-70 gibi oldukça yüksek oranda olup, önemini korumaktadır (3).

Sağlık çalışanlarının kan ve vücut sıvıları ile temasına neden olan faktörlerin bilinmesi, bulaşmayı önlemeye yönelik önlemlerin alınması ve spesifik enfeksiyonlara yönelik bilgilerinin devamlı güncellenmesi önleme programlarının geliştirilmesinde ve uygulanmasında anahtar role sahiptir. Bununla birlikte bulaşmanın ve koruyucu önlemlerin bireysel, işlemsel ve kurumlarla (sağlık çalışanı, yaralanmaya neden olan uygulama, yaralanmanın yaşandığı yer) ilgili özelliklerinin belirlenmesi önleme programlarının hedefe yönelik kısmının geliştirilmesinde etkili olacaktır (3).

Hastanemizde çalışan sağlık personellerinin kan ve vücut sıvılarına maruziyet durumu, maruziyetin hangi materyalle meydana geldiği, olay sırasında koruyucu ekipman kullanımı, personelin tutumu, kesici delici alet yaralanması hakkındaki bilgi düzeyi ve maruziyet sonrasında olay bildirim formunun doldurulması ile ilgili bir anket yapılması planlandı ve sonuçların çalışanlar ve hastane idaresi açısından yeterli ve gerekli farkındalığın gelişmesi için yapılması gerekenler konusuna ışık tutması amaçlandı.

\section{Gereç ve Yöntem}

Tanımlayıcı ve kesitsel tipte olan bu çalışma 2011 yılı içinde Bağcılar Eğitim ve Araştırma Hastanesi'nde yapıldı. Araştırma verilerini elde etmek için 270 kişiye (40 hekim, 155 hemşire, 54 yardımcı sağlık personeli, 7 teknisyen ve diğer 14 kişi-perfüzyonist, öğrenci hemşire, tekniker) 18 sorudan oluşan anket uygulanmıştır. Anket, çoktan seçmeli sorulardan oluşmuş ve araştırmacılar tarafından literatür bilgisinden yararlanılarak hazırlanmıştır. Anket katılımcıları bilgilendirilmiş ve anketi kendilerinin doldurmaları istenmiştir.

İki bölüm olarak hazırlanan anketin ilk altı sorusunda ankete katılanların sosyo-demografik özellikleri ile ilgili verileri elde etmeye yönelik bilgilere yer verilmiştir (Yaş, cinsiyet, eğitim düzeyi, meslek, çalışma yılı ve çalışılan birim). İkinci bölümde KDAY eğitimi alıp almadıkları ve maruz kaldıkları yaralanmaların hangi işlem sırasında olduğu, koruyucu ekipmanın varlığı, KDAY sonrasında neler yaptıklarını belirlemeye yönelik sorular yer almıştır. Anketin son bölümünde ise alınması gereken önlemler konusunda katılımcıların görüşlerine başvurulmuştur.

Çalışma öncesi, Bağcılar Eğitim ve Araştırma Hastane Başhekimliği'nden yazılı izin alındı. Araştırmaya gönüllü olarak katılanlar örneklem grubuna dahil edildi. Enfeksiyon Kontrol Hemşireleri koordinasyonu ile her bir sağlık çalışanından formları kendilerinin doldurması istendi.

\section{Bulgular}

Çalışanların \%56'sı 20-30 yaş arasında ve \%9'u 40 yaşın üzerindeydi ve \%73'ü 1-5 yıl arasında çalışmışlardı. Kadın cinsiyet, çalışma grubunun \%64'ünü oluşturuyordu. Anket katılımcılarının \%39'u üniversite eğitimi almıştı. Acil, YBÜ ve ameliyathane çalışanları katılımcıların \%44'ünü oluşturmaktaydı. KDAY maruziyetinin mesleklere göre dağılımı grafikte görülmektedir (Grafik 1).

En sık yaralanma nedenleri incelendiğinde ameliyat sırasında (aleti elden ele geçirirken ya da kesici delici aletle çalışan birisi ile çarpışma) \%21, hastadaki iğnenin manipülasyonu (IV kanül takılması, enjeksiyon uygulamaları) \%17, uygulama sonrası temizlik sırasında \%17, kan alma sırasında \%16, iğne ucunu kapama sırasında \%14, atıkların atılması sırasında (tıbbi atık kutusuna atılma sırasında, atıkların yanlış atılması, kesici delici atık kutusunu kapatırken) \%15 ve diğer uygulamalar sırasında (kan şekeri bakılması, kan ve vücut sıvılarının sıçraması) \%9 olarak görülmüştür (Grafik 2).

Yaralanma sonrası yapılan en sık uygulama su ve sabun ile yıkama (\%39) idi. Yaralanmayı izleyerek en sık birim sorumlusuna haber verilmişti (\%19). "Bir şey yapmadım" diyenlerin oranı \%25 idi ve nedeni sorgulandığında hekimler ve

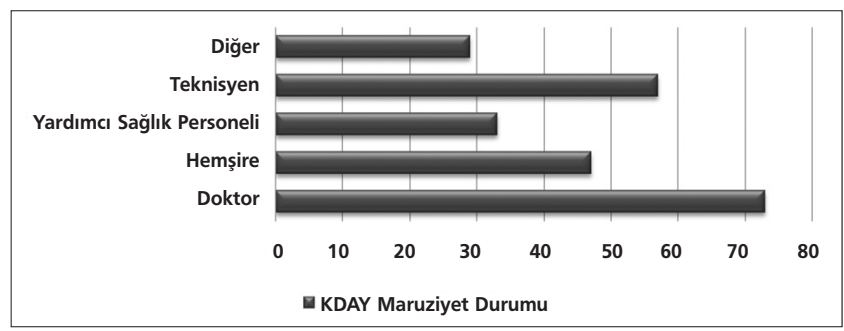

Grafik 1. KDAY maruziyetinin meslek gruplarına göre dağılımı 
hemşireler tarafından en sık olarak "Önemsiz olarak gördüm" şıkkı işaretlenmişti (Grafik 3).

KDAY sonrası yapılan işlemlerin meslek gruplarına göre dağıımları incelendiğinde en fazla doktorların yaraya yönelik işlem yaptıkları ama hiçbirinin form doldurmadığı görülmüştür (Tablo 1).

KDAY hakkında bilgiye katılımcıların \%97'si sahipti ve \%76'sı eğitim almıştı. Kan yolu ile bulaşan hastalıklar hakkında (HIV, HBV, HCV, kanamalı ateşler), hepsini bilen katıımcı oranı \%65 idi. Koruyucu ekipman kullanım oranları

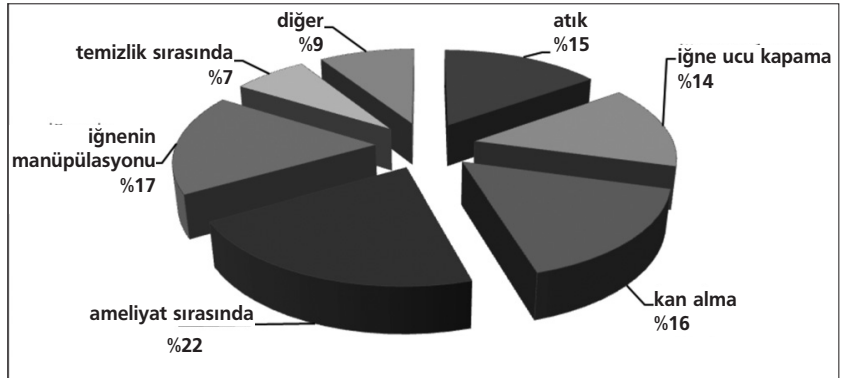

Grafik 2. Yaralanma nedenlerinin dağıım yüzdeleri

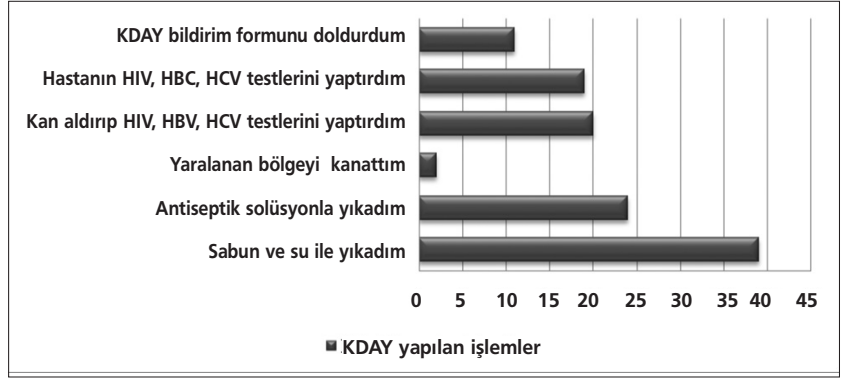

Grafik 3. KDAY sonrası yapılan işlemlerin dağııımı

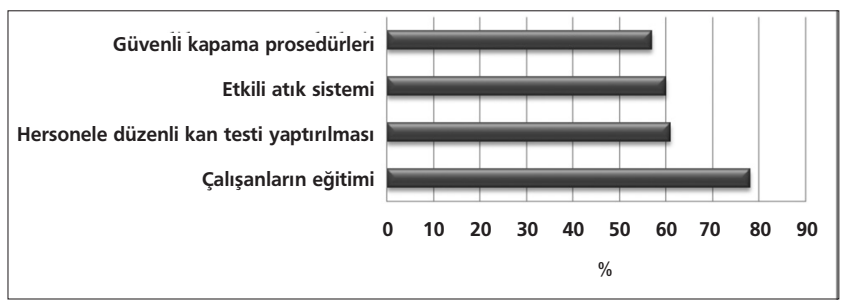

Grafik 4. Yönetimden beklentiler eldiven $\% 45$, maske $\% 19$, önlük \%17 ve gözlük \%4 olarak saptandı. Yönetimden beklentiler arasında en sıkıkla verilen cevap ise çalışanların eğitimi (\%78) idi (Grafik 4).

\section{Tartışma}

Hastanemiz 2006 yılında hasta kabulüne başlamıştır ve Bağcılar, Esenler, Güngören ilçelerinin kesiştiği bölgede yaklaşık 2 milyon nüfusa hizmet vermektedir. 2000'e yakın personelin çalıştığı, 498 yatak kapasiteli ve yılda ortalama $1,800,000$ hasta muayene edilen hastanemizde 36 yoğun bakım yatağı vardır ve hasta naklinde 112 hava ambulansı hizmeti verilmektedir. Ayrıca yılda ortalama 130 öğrenci hemşire, laboratuvar ve benzeri birimlerde staj yapmaktadır.

Anketimizde, çalışanların \%56'sı 20-30 yaş arasında ve \%73'ü 1-5 yıl arasında çalışmışlardı. Kadın cinsiyet, çalışma grubunun \%64'ünü oluşturuyordu. Üniversite eğitimini anket katılımcılarının \%39'u almıştı. KDAY hakkında bilgiye katılımcıların \%97'si sahipti ve \%76'sı eğitim almıştı. Bu sonuçlara göre çalışanlarımız genç ve deneyimsiz bir grubu oluşturmaktadır (4). Kan yolu ile bulaşan hastalıklar hakkında (HIV, HBV, HCV, kanamalı ateşler), hepsini bilen katılımcı oranı $\% 65$ idi. Blackwell ve ark. yaptıkları çalışmalarında tıp ve hemşirelik öğrencilerinin yarısından çoğunun hasta kan ve vücut sıvılarıyla temas yaşadığını, çok azının bu durumu rapor ettiğini, kesici ve delici aletlerle yaralanan öğrencilerin HIV, HBV, HCV gibi potansiyel enfeksiyonlara maruz kalma korkusu yaşadıklarını tespit etmişlerdir (5). Bir başka çalışmada klinik deneyimlerinin yetersiz olması nedeniyle klinik uygulamalar sırasında tıp ve hemşirelik öğrencileri KDAY açısından özellikle risk grubundadır. Çalışmalarda tıp öğrencilerinin eğitimleri süresince \%11-50, hemşirelik öğrencilerinin ise \%50-80 arasında kesici ve delici aletlerle yaralanmaya maruz kaldığı belirtilmiştir (6).

Hastanemizde 2011 yılı içinde 117 KDAY yaşanmıştır. KDAY maruziyeti sonrası form doldurarak bildirim yapan sağlık personelinin meslek gruplarına göre dağılımı ile ankete cevap veren personele ait bilgiler bir grafik üzerinde karşılaştııılmıştır (Grafik 5). KDAY maruziyeti sonrası doktor grubunda bildirim oranlarının düşük olduğu tespit edilmiştir. Hemşirelerde tüm KDAY maruziyetlerinin kayıt altına alındığı ama bu durumun doktorlar ve yardımcı sağlık personeli için geçerli olmadığı ve bu gruplarda bildirim

Tablo 1. KDAY sonrası yapılan işlemlerin meslek gruplarına göre dağılım yüzdeleri

\begin{tabular}{lccc}
\hline KDAY sonrası yapılan işlem & Doktor \% & Hemşire \% & Diğer yardımc sağlık personeli \% \\
\hline Sabun ve su ile yıkadım & 50 & 42 & 28 \\
Antiseptik solüsyonla yıkadım & 48 & 23 & 13 \\
Yaralanan bölgeyi kanattım & 3 & 1 & 1 \\
Kan aldırıp HIV, HBV, HCV testlerini yaptırdım & 33 & 22 & 8 \\
Hastanın HIV, HBV, HCV testlerini yaptırdım & 40 & 18 & 8 \\
KDAY bildirim formunu doldurdum & 0 & 14 & 12 \\
\hline
\end{tabular}




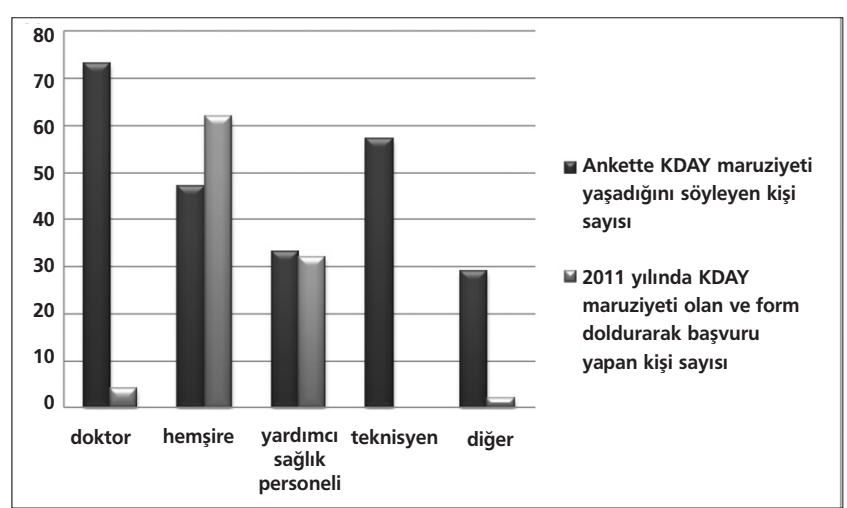

Grafik 5. Anket cevapları ile (KDAY maruziyeti bildirimi) 2011 yılında yaşanan ve form doldurularak bildirimi yapılan KDAY deneyimlerinin meslek gruplarına dağılımı

yapmanın gerekliliği konusunda eğitimlerin artırıması gerektiği düşünülmüştür.

Anketimize göre KDAY sonrası "Bir șey yapmadım" diyenlerin oranı \%25 idi ve nedeni sorgulandığında hekimler ve hemşireler tarafından en sık olarak "Önemsiz olarak gördüm" şıkkı işaretlenmişti. Sağık çalışanlarının mesleki temas bakımından koruyucu önlemleri ve temas sonrası izlem prosedürlerini yeterince önemsemediğini gösteren bu sonuç; konuya dikkat çekmek için daha fazla farkındalık yaratmak gerektiğini düşündürmektedir. Bir başka çalışmanın sonuçlarına göre, kan ve vücut sıvılarına mesleki temastan en fazla etkilenen sağlık çalışanlarının hemşireler olduğu gösterilmiştir (7). Bu sonucun, hemşire başına düşen hasta sayısının fazla olması, işlerini aceleyle yapmaları, bakım, tedavi, IV kanül takma, kan alma ve malzemelerin temizliği gibi birden çok işlemden sorumlu olmalarıyla ilişkili olabileceği öne sürülmüşsür (3).

Anketimizde en sık yaralanma nedeni; kan alma (\%12), iğne ucu kapatma (\%11) ve ameliyat sırasında meydana gelen yaralanmalar (\%10) olarak saptandı. Son on yıldır perkütan yaralanmaları en aza indirmeye yönelik güvenli tıbbi malzemeler (iğneyi enjektörden ayırmadan atılabilecek, kutunun tamamen dolmasını/elin atıklara değmesini engelleyen atık kutuları; kullanıldıktan sonra içeri çekilebilir ya da iğnenin üzerine kayan başlık sistemleri olan iğne, enjektörler vb.) sağlık bakım hizmetinde kullanılmaya başlanmışıır. Ancak ülkemizde bazı güvenlikli ürünlerin maliyetinin yüksek olması kullanımları sınıllandırmaktadır (6).

Yaralanma sonrası yapılan en sık uygulama su ve sabun ile yıkama (\%39) idi. Yaralanmayı izleyerek en sık birim sorumlusuna haber verilmiști (\%19). Temas sonrası KDAY'a maruz kalan bölgenin, bol su ve sabunla yıkanması ve bir cilt antiseptiği ile temizlenmesi tüm etkenlerle ilgili etkin ve temel yaklaşımdır. Sonra kaynağın ve maruz kalan sağlık çalışanının risk değerlendirmesi yapıımalı, bir takip ve tedavi programı oluşturulmalıdır. Bu program bir merkezden planlanmalı ve izlenmelidir (8).

Anketimizde koruyucu ekipman kullanım oranları eldiven $\% 45$, maske $\% 19$, önlük \%17 ve gözlük \%4 olarak saptandı.
Yönetimden beklentiler arasında en sıklıkla verilen cevap ise çalışanların eğitimi (\%78), personele düzenli kan testi yaptırıması (\%61), etkili atık sistemi (\%60) ve güvenli kapama prosedürleri (\%57) idi. Enfeksiyon ajanları kan yoluyla insanlara iki şekilde bulaşmaktadır: birincisi direkt kan ve kan ürünlerinin alımı, ikincisi ise kazara kanın temasıdır. Kazara temas iki yol ile olmaktadır: Perkütanoz yol (enjektör ya da diğer sivri uçlu aletlerin batması, kesici aletler ile derinin kesilmesi ve soyulması, derinin diğer hasar ve yanıkları) ve mukozal yol (ağız, burun ve konjunktivaya kanın sıçraması). Ayrıca kan içeren diğer vücut sıvıları ile de bulaş ortaya çıkmaktadır (amniyotik, serebrospinal, perikardiyal, peritoneal, plevral, sinovyal sıvilar, vajinal sekresyonlar, semen ve tükürük) $(9,10)$.

Anket çalışmaları hem dikkat çekilmek istenen konu hakkında bir farkındalık yaratmakta hem de konunun sorumlularına varılmak istenen hedefe uzaklık konusunda bilgi vermektedir. Özellikle eksiklerin ve yanlışların görülmesi açısından anket çalışmaları son derece önemlidir. Yapılan bu anket çalışması; özellikle hekimler ve yardımcı sağlık personelinin bu konuda eğitimlerinin arttırılması ve kayıt prosedürlerine uyumu sağlamak için de yeni yaklaşımlar geliştirilmesi gerektiğini göstermiştir. Ayrıca koruyucu ekipman kullanımının artırıması için hem hastane idaresine yönelik, hem de personelin bu konuya ilgisini çekmeye yönelik girişimler başlatı Imıştır.

\section{Kaynaklar}

1. Doyuk Kartal E. Sağlık personelinde profilaksi. İstanbul Üniversitesi Cerrahpaşa Tıp Fakültesi Sürekli Tıp Eğitimi Etkinlikleri Sempozyum Kitabı, Şubat 2008, İstanbul. s.215-222.

2. Korkmaz M. Sağlık çalışanlarında delici kesici alet yaralanmaları. Fırat Sağlık Hizmetleri Dergisi 2008;3:17-37.

3. Altıok M, Kuyurtar F, Karaçorlu S, Ersöz G, Erdoğan S. Sağlık çalışanlarının delici kesici aletlerle yaralanma deneyimleri ve yaralanmaya yönelik alınan önlemler. Maltepe Üniversitesi Hemşirelik Bilim ve Sanatı Dergisi 2009;2:70-9.

4. Martins A, Coelho AC, Vieira M, Matos M, Pinto ML. Age and years in practice as factors associated with needlestick and sharps injuries among health care workers in a Portuguese hospital. Accid Anal Prev 2012;47:11-5.

5. Blackwell L, Bolding J, Cheely E, et al. Nursing students' experiences with needle stick Injuries. Journal of Undergraduate Nursing Scholarship 2007;9(1).

6. Kuyurtar F, Altıok M. Tıp ve hemşire öğrencilerinin delici kesici aletlerle yaralanma deneyimleri ve aldıkları önlemler. Fırat Sağlık Hizmetleri Dergisi 2009;4:67-84.

7. Erol S, Özkurt Z, Ertek M, Kadanalı A, Taşyaran M A. Sağlık çalışanlarında kan ve vücut sıvılarıyla olan mesleki temaslar. Hastane Enfeksiyonları Dergisi 2005;9:101-6.

8. Aygün P. Kesici delici alet yaralanmaları ve korunma önlemleri. 5. Ulusal Sterilizasyon Dezenfeksiyon Kongresi Kitabı, 4-8 Nisan 2007, Antalya. s.385-391.

9. Akbulut A. Kan yoluyla bulaşan enfeksiyonlar. Hastane Enfeksiyonları Dergisi 2007;11:242-5.

10. Chen LF, Sexton DJ, Kaye KS, Anderson DJ. Patient-days: A beter measure of incidence of occupational bloodborne exposures. Am J Infect Control 2009:37:534-40. 